\title{
The Correlation between Critical Thinking Skills and Cognitive Learning Outcomes
}

\author{
Hasan Tuaputty, Pattimura-University, Indonesia, tuaputtyhasan@gmail.com, ORCID: 0000-0002-0556-5102 \\ Marleny Leasa, Pattimura University, Indonesia, marlenyleasa3@gmail.com, ORCID: 0000-0003-0718-3447 \\ Aloysius Duran Corebima, University of Kanjuruhan Malang, Indonesia, durancorebima@gmail.com, ORCID: 0000- \\ 0002-2632-9467
}

John Rafafy Batlolona, Pattimura University, Indonesia, johanbatlolona@gmail.com, ORCID: 0000-0003-3447-7432

\begin{abstract}
This correlational research aims to reveal the contribution of critical thinking skills (CTS) toward cognitive learning outcomes (CLO) on the learning using NHT and metacognitive strategies, and to reveal the differences in regression equations between the two learning models. The results revealed that there was a correlation between CTS and CLO in both the NHT and metacognitive strategies. The biggest contribution of CTS toward the students' CLO was found in the NHT + metacognitive strategy learning model, which was $71.4 \%$, and the regression equation of the learning model was $Y=21.66+0.72$ $X$. The results of Anova show the significance value of $b 1, b 2$ was $0.009(p<0.05)$ and the significance value of $b 1, b 2, b 3$ was $0,000(p<0.05)$. Thus, the rate and magnitude of the student CLO as an effect of the CTS are different from each other. These results prove the NHT learning model and metacognitive strategy is more effective in empowering CTS and CLO.
\end{abstract}

Keywords: Critical thinking skills, cognitive learning results, NHT learning model, metacognitive strategy

Received: 15.05 .2020

Accepted: 29.08 .2020

Published: 15.01.2021

\section{INTRODUCTION}

Cognitive learning outcomes is the level of specific academic ability gained based on standard test results through a series of test results. The information is then decided whether the students experience graduation, failure, and rank and grade levels that will then be useful in entering the next level of education or to apply for a job (Mathew, 2017). The cognitive learning outcomes (CLO) refer to the intellectual skills possessed by a person. The achievement of CLO cannot be separated from students' affective and psychomotor abilities. This is because learning behavior is related to cognitive, affective, and psychomotor domains. High CLO can provide opportunities for students to develop their affective and psychomotor domains (Galloway \& Bretz, 2015).

Information about students' CLO is beneficial for the students themselves as well as for the teachers. The students can use the information to know their learning progress, to know the concepts or materials that have not been mastered, as a source of self-motivation to learn better, and to improve the way, style, or learning strategy. For teachers, the information is beneficial to encourage them to teach better, to help determine a more appropriate learning strategy/model for the classroom learning, and to encourage schools to provide better learning facilities. On the other hand, the information on the achievement of students' CLO is needed to examine the various factors that are thought to influence the learning outcomes, one of which is the students' critical thinking skills (Shirazi \& Heidari, 2019; Karbalaei, 2012).

Critical thinking skills (CTS) are an active and organized cognitive process which is done to understand ourselves and to familiarize us with what is happening around by being aware of our own thinking process, as well as considering the thinking processes of others and applying what we already have (Danczak, Thompson, \& Overton, 2020). Thus, critical thinking requires a high level of abstract and logical thinking and a commitment or habit of thinking to meet the standards and principles of good critical thinking. Such skills are defined as reflective and reasoned ways of thinking that are focused on deciding what the individuals believe and can do (van Peppen et al., 2018). Delphi's consensus involving various experts managed to discuss 
about CTS as the purpose of assessment and learning. The consensus defines CTS as a selfassessing skill of the results of interpretation, analysis, evaluation, inference, and explanation to make decisions which consider the concepts, methodologies, criteria, and contexts (Facione, 2011).

The need to teach and develop CTS becomes an important part of today's learning era. Over the years, educators / instructors have sought to discover important elements of thought and a number of methodical approaches to teaching thinking skills as an essential part of the curriculum (López et al., 2020). One of the important goals of education is developing CTS. This allows students to make wise, independent choices, and to able to judge something independently and selectively. The development of the times, technology, and science demands the need for such skills to play an effective role in the modern (Peter \& Facione, 2013). Teachers need to equip and empower students' CTS, so that they are ready to compete and to be successful in facing the increasingly rapid challenges and world changes (Cheng \& Wan, 2017). The learning process at various levels of education in Indonesia is less directed to the empowerment of thinking skills, including the CTS (Wartono, Hudha, \& Batlolona, 2018).

Science learning at the primary school level is one of the media to develop thinking skills. The optimization of science to empower human can be done by studying science as much as possible and revealing the information as much and as deep as possible (Hulleman \& Harackiewicz, 2009). This means that the students' potential can be optimized through an understanding of science. Conversely, science that is limited by the students' experience will grow quickly along with the empowerment of students' thinking skills.

CTS are related to the achievement of CLO. A person who has good CTS will certainly have good learning results, and vice versa. CTS is an intellectual excellence that is needed to construct a person's academic ability and achievements as well as to create a harmonious social life in the midst of plurality (Erikson \& Erikson, 2019; Almeida \& Franco, 2011). In line with this, CTS are now of concern in various studies to promote the positive effect of CTS on students' CLO or academic achievement (Wei, 2020). Furthermore, the research results by (George- William et al., 2019) showed a positive correlation between critical thinking scores and students' CLO. Thus, the students who have high CTS will also have high CLO. Critical thinking has a positive correlation with the achievement of students' (Erikson \& Erikson, 2019).

A variety of constructivist-based learning models can be used in empowering students' CTS including Numbered Heads Together (NHT) (Hunter, Dieker, \& Whitney, 2016). NHT emphasizes on the individual responsibility in learning, and provides opportunities for all students to actively participate in thinking regardless of the limiting factors. One of the processes of the NHT type of cooperative learning model which is thought to be beneficial for the achievement of CLO is social interaction. Knowledge is built through the interaction of individuals in society, and learning can be considered a result of the internalization of social interactions. Interaction exposes the individual to the diversity of personal styles, experiences, attitudes, ideas, and opinions. This interaction causes the learning process to be better and supports the student academic progress (Slavin, 2014; Marcos al., 2020).

NHT is easy to organize in learning for elementary students because it uses accessories for grouping students in the form of numbering on the head that attracts students' attention. In its implementation, the numbering is used as a hat on the head so that it makes it easier for students to organize students to answer questions and discuss them during learning. Natural science learning in SD is carried out with a limited allocation of hours (only 70 minutes) so this model is used because it can be circumvented through group learning arrangements. This model encourages the responsibility of each individual in learning so that students try to master learning as much as possible (Leasa \& Corebima, 2017).

Learning needs to be supported with appropriate metacognitive strategies (Cai, King, Law, \& McInerney, 2019). Metacognitive strategy is an attempt to monitor the cognitive strategies used by a person to achieve the ultimate learning goal (Wagaba, Treagust, Chandrasegaran, \& Won, 2016). Metacognitive strategies in the form of making a summary and self-assessing are able to familiarize students in distinguishing which information has been 
learned and which has not, to learn various new information, and help students reflect on the learning processes that have been done, to prepare entering the next learning process. Furthermore, metacognitive strategy through self-assessing is very useful for students. Through this strategy students can explore, find and express the strength and the weaknesses of themselves in various things, and able to address and improve their weaknesses (Shannon, 2008).

Several previous researches have revealed the correlation between CTS and CLO through a particular learning model/strategy. Amin et al., (2020) used a Reciprocal Teaching (RT) learning strategy to examine the correlation between metacognitive skills and Biology critical thinking of UIN Alauddin Makassar and STKIP YAPIM Maros, South Sulawesi in Makassar. Another research reveals the correlation between metacognitive skills and critical thinking skills on learning outcomes using Problem Based Learning (PBL) learning model (Downing, Ning, \& Shin, 2011). Similarly, research investigated the correlation between basic political science and the learning outcomes of geographical students using Group Investigation (GI) learning model (Sugiharto, 2020). From the results of this research, it was concluded that CTS can be used to predict the CLO in a particular learning model used. In relation to the use of the NHT learning model, previous research have revealed the effect of NHT learning model on learning outcomes and CTS (Hunter \& Haydon, 2013). This indicates that the information about the correlation between CTS and CLO by using NHT learning model, as well as NHT + metacognitive strategy is still very limited.

From various reference searches, studies of the relationship between critical thinking and student learning outcomes are generally revealed at the tertiary level, while at the basic education level it is almost not found. Akpur (2020) examines the relationship between critical thinking and student learning outcomes in Turkey. The indicators of critical thinking that are studied include reasoning, decide based upon evidence, recognizing the problem, and information acquisition. The results showed a positive relationship between critical thinking and learning outcomes and critical thinking was a significant factor in predicting student learning outcomes. Similar research was also carried out by D'Alessio, Avolio, \& Charles (2019) on MBA executive students using the Watson Glaser Critical Thinking Appraisal test (WGCTA). The dimensions of critical thinking studied include: drawing inferences, recognizing assumptions, argument evaluation, deductive reasoning, and logical interpretation. Jacob (2012) also researched to examine the relationship between critical thinking and learning outcomes of engineering students who offer engineering mathematics courses. The research findings reveal that there is a significant linear relationship between critical thinking and mathematics learning outcomes. The CT used is the CAIS model consisting of Clarification, Assessment, Inference, and Strategies. A similar study by Kanbay et al., (2017) examined critical thinking and learning outcomes in nursing students using the California Critical Thinking Disposition Inventory. The result is a positive relationship but at a low level the relationship between critical thinking and learning outcomes. Fong et al., (2017) also concluded that the results of the meta-analysis showed a positive relationship between critical thinking and student success. So the novelty of this research is to examine the relationship between critical thinking skills and learning outcomes in elementary school science learning, by referring to Facione (2011) critical thinking indicators which include interpretation, analysis, inference, explanation, and evaluation.

Based on the research background presented, this research is important to conduct. This is done to reveal the potential of NHT and NHT + metacognitive strategies concerning critical thinking skills and learning outcomes. Both of these models are easy to implement, simple, and fun. Metacognitive dimensions, critical thinking, and learning outcomes, especially HOTS, are very important to develop students' thinking skills. NHT, NHT + metacognitive strategies are also a combination of learning models oriented towards the development of metacognitive students, especially in elementary school science learning (Leasa, 2017). On another aspect, science learning places great emphasis on students' higher-order thinking rather than just memorizing facts. Metacognition in the classroom can improve overall learning outcomes as 
well as higher-order thinking in particular (Veenman, 2011). Science learning, especially in elementary schools, which touches the aspects of thinking skills, needs to be encouraged to spur logical thinking in solving problems encountered in everyday life (Zohar, 2013).

The purpose of this research is to explore the contribution of students' CTS toward learning results by using NHT learning model and NHT + metacognitive strategy especially in science learning in elementary schools. Besides this research is also to compare the equation of the regression line of the two learning models. The results of this research are expected to provide more relevant information for teachers in selecting effective learning models which potentially improve students' CTS and CLO. This information can be a reference material for teachers in developing and designing strategic learning models to spur critical thinking skills and student learning outcomes.

\section{METHODS}

\section{Type of research}

This is a correlational research which aims at revealing the contribution of CTS towards CLO through the NHT model, NHT + metacognitive strategy, and to reveal the differences in regression equations between the two learning models. CTS were the predictor variables, and the CLO were the criterion variables. CTS variables were built by several indicators namely: interpretation, analysis, inference, explanation, and evaluation (Facione, 2016). The CLO variables consisted of six indicators or C1-C6 levels that included the indicators of remembering, understanding, applying, analyzing, evaluating, and creating (Krathwohl, 2002).

\section{Population and sample of the research}

The population in this research was the students of class V Elementary School in Ambon City. The total number of the samples was 137 students that were randomly determined. The 137 students consist of 66 female students and 71 male students. Participants or samples aged between 10-12 years. All students involved in this study accomplished all responsibility for providing data during the study and did not object to their involvement. The samples were obtained from 6 elementary schools (8 classes) in Ambon City spreading over 3 districts, namely Nusaniwe, Sirimau, and Baguala. The school samples used in this research had been given an equality tests. Thus, the students scattered in various schools were equal to one another.

This study follows the ethics of data collection in the form of research permits in schools. The procedure for obtaining a permit is based on several procedures. First, there is a research permit from the institution where the researcher works for the governor of Maluku through the Head of Bakesbangpol. Second, the licensing process is then processed by Bakesbangpol Maluku to issue a notification letter for research conducted at the location of the education and sports office in Ambon city. Third, the letter becomes the basis for the Ambon mayor to issue data collection at several primary schools in Ambon city.

\section{Data collection}

The data of CTS and CLO were obtained from the learning outcomes tests in the form of pretest and posttest. The pretest was carried out before the treatment using NHT learning model, NHT + metacognitive strategy was given, while the posttest was carried out after treatment using the same learning models was given. Data collection was carried out at the beginning of the odd semester, namely August-December 2015/2016 academic year. According to the calendar for the academic year in the semester, August-December is indeed the week of learning activities. These months are the effective time for implementing the odd semester after the school enters the long holiday of the previous school year, which ends in June. The implementation of learning programs using NHT learning model and NHT + metacognitive strategy was done for one semester (4 months), with 26 meetings. 


\section{Research instrument}

The research instruments used were in the form of tests of CTS integrated with CLO in an essay form. The test instruments were developed by the researchers based on the indicators of CTS and CLO referring to the scope of the materials that had been taught to the students. The instrument was developed by researchers because the content of elementary school science learning in odd semesters in the curriculum in Indonesia is different from science learning in other countries. To efficiency the implementation of the learning outcomes test, an integrated test is carried out, namely a critical thinking skill test and learning outcome which is designed in one test package. This is done to avoid elementary school students' boredom in doing many and repetitive test questions. So within 2 lesson hours (70 minutes) students can complete the test questions. This instruments had been through the construct validation and empirical testing. The test of CTS and learning outcomes consisted of 12 and 18 items. The validity and reliability of the CTS test instruments were 0.76 and 0.93 , the validity and reliability of the CLO were 0.68 and 0.93. Examples of CTS and CLO items given to students for the pretest and posttest are shown in Table 1.

Table 1. Examples of CTS and CLO items

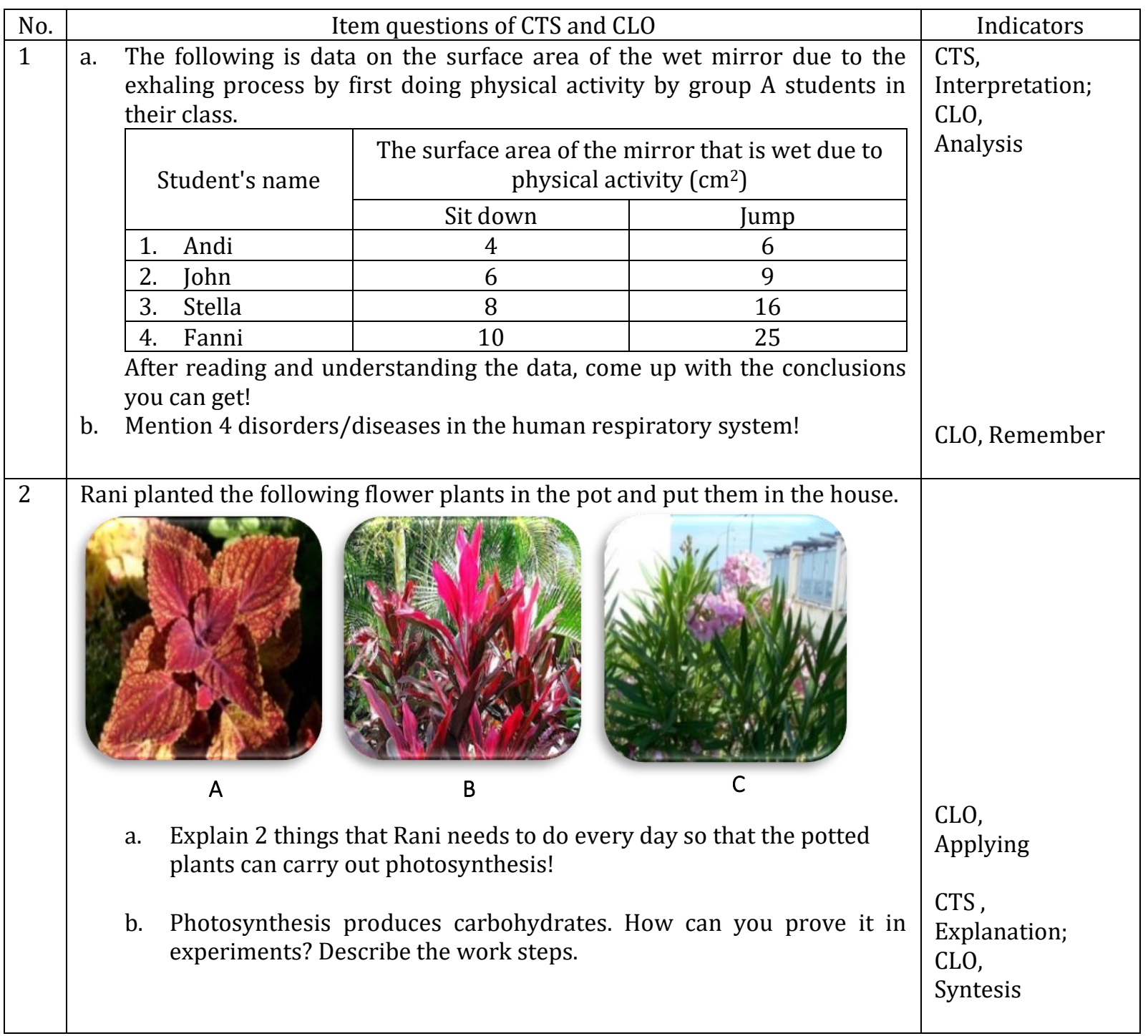




\section{Data analysis technique}

Data of CTS and CLO in the form of pretest and posttest value were tabulated, and then calculated for the corrected score. Before analyzed, the data were ensured to be normal by performing normality test using One Sample Kolmogorov Smirnov Test. The normality of CTS and CLO on NHT model and NHT + metacognitive strategy was equal that is 0.200 . It means that the data had been normal. The data were then analyzed by using inferential statistics (simple linear regression) to test the correlation between the two variables, while to examine the difference of regression equations between NHT model and NHT + metacognitive strategy used Anova. The whole process of data analysis was done with SPSS 23.00 for Windows program. The interpretation of the value of $r$ according to Cohen, Manion, \& Morrison (2000) is presented in the following table.

Table 2. Interpretation of the value of $r$

\begin{tabular}{|c|c|}
\hline$r$ values & Interpretation \\
\hline $0.00-0.19$ & Very low \\
$0.20-0.34$ & Low \\
$0.35-0.64$ & Moderate \\
$0.65-0.84$ & Strong \\
$0.85-1.00$ & Very strong \\
\hline
\end{tabular}

\section{RESULTS}

The data description of corrected mean of CTS and CLO on NHT learning model and NHT + metacognitive strategy are shown in Table 3.

Table 3. Corrected mean of CTS and CLO

\begin{tabular}{ccccc}
\hline Model & Variable & Corrected Mean & Std. Deviation & N \\
\hline \multirow{2}{*}{ NHT } & CLO & 59.08 & 9.99 & 67 \\
& CTS & 57.72 & 10.79 & 67 \\
\multirow{2}{*}{ NHT+Meta } & CLO & 71.15 & 9.51 & 70 \\
& CTS & 68.49 & 11.13 & 70 \\
\hline
\end{tabular}

Table 3 shows that the corrected mean of CLO in NHT learning model and NHT + metacognitive strategy are 59.08 and 71.15 , respectively. While the corrected mean of CTS in both learning models is 57.72 and 68.49 . This suggests that the corrected mean score on the NHT learning model + metacognitive strategy is greater than that of the NHT learning model.

Based on the results of Anova that describes the correlation between CTS and CLO in the NHT learning model, it is known that the significance value $=0.00(p<0.05)$. This means that there is a correlation between CTS and CLO in the NHT learning model. The Anova results are shown in Table 4.

Table 4. Summary of Anova on the correlation between CTS and CLO in the NHT

\begin{tabular}{llcrrrr}
\multicolumn{7}{c}{ ANOVA $^{\text {a }}$} \\
\hline & Model & Sum of Squares & $\mathrm{df}$ & Mean Square & F & Sig. \\
\hline \multirow{2}{*}{1} & Regression & 1341.52 & 1 & 1341.52 & 16.62 & $.00^{\mathrm{b}}$ \\
& Residual & 5246.85 & 65 & 80.72 & & \\
& Total & 6588.38 & 66 & & & \\
\hline
\end{tabular}

a. Dependent Variable: CLONHT

b. Predictors: (Constant), CTSNHT

In the NHT learning model + metacognitive strategy, the results of Anova show that the significance value of the correlation between CTS and learning outcome was $0.00(p<0.05)$. This means that there is a correlation between CTS and CLO in the NHT learning model + metacognitive strategy. The results of Anova are shown in Table 5. 
Table 5. The results of Anova on the correlation between CTS and CLO in the NHT + metacognitive strategy

\begin{tabular}{llcrrrr}
\multicolumn{8}{c}{ ANOVA $^{\text {a }}$} \\
\hline & Model & Sum of Squares & df & Mean Square & F & Sig. \\
\hline \multirow{2}{*}{1} & Regression & 4458.12 & 1 & 4458.12 & 169.90 & $.00^{\mathrm{b}}$ \\
& Residual & 1784.09 & 68 & 26.24 & & \\
& Total & 6242.21 & 69 & & & \\
\hline
\end{tabular}

a. Dependent Variable: CLONHTMETA

b. Predictors: (Constant), CTSNHTMETA

The magnitude of the contribution of CTS toward CLO in the NHT learning model is shown in Table 6. Table 6 shows that the R value on the correlation between CTS and CLO in NHT learning model is 0.451 or included in the moderate correlation level (Cohen, Manion, \& Morrison, 2000) and $\mathrm{R}^{2}$ value is as much as 0.204 or $20.4 \%$. Thus, the aspect of CTS gave contribution as much as $20.4 \%$ to the achievement of CLO and other factors gave contribution as much as $79.6 \%$.

Table 6. Summary of linear regression of the correlation between CTS and CLO in the NHT

\section{Model Summary}

\begin{tabular}{ccccc}
\hline Model & $\mathrm{R}$ & R Square & Adjusted R Square & Std. Error of the Estimate \\
\hline 1 & $.451^{\mathrm{a}}$ & .204 & .191 & 8.984 \\
\hline
\end{tabular}

a. Predictors: (Constant), CTSNHT

The magnitude of the contribution of CTS toward CLO in the NHT learning model + metacognitive strategy are shown in Table 7 . Table 7 shows that the $\mathrm{R}$ value on the correlation between CTS and CLO in the NHT learning model + metacognitive strategy was 0.845 or included as strong correlation (Cohen, Manion, \& Morrison, 2000) and the $\mathrm{R}^{2}$ value was 0.714 or 71.4\%. Thus, in the NHT learning model + metacognitive strategy, the CTS factor gave contribution as much as $71.4 \%$ to the achievement of CLO and other factors gave contribution as much as $28.6 \%$.

Table 7. Summary of linear regression correlation between CTS and CLO in the NHT + metacognitive strategy

\begin{tabular}{ccccc}
\multicolumn{5}{c}{ Model Summary } \\
\hline Model & R & R Square & Adjusted R Square & Std. Error of the Estimate \\
\hline 1 & $.845^{\mathrm{a}}$ & .714 & .710 & 5.122 \\
\hline
\end{tabular}

a. Predictors: (Constant), CTS NHTMETA

The regression equation analysis of the correlation between CTS and CLO related to the NHT learning model is shown in Table 8. Since the values of $a=34.979$ and $b=0.418$, the regression equation on the NHT learning model is $Y=34.979+0.418 X$.

Table 8. The regression coefficient value between CTS and CLO $n$ the NHT

\begin{tabular}{|c|c|c|c|c|c|c|}
\hline \multicolumn{7}{|c|}{ Coefficients $^{a}$} \\
\hline & \multirow{2}{*}{ Model } & \multicolumn{2}{|c|}{ Unstandardized Coefficients } & \multirow{2}{*}{$\frac{\text { Standardized Coefficients }}{\text { Beta }}$} & \multirow{2}{*}{$\mathrm{t}$} & \multirow{2}{*}{ Sig. } \\
\hline & & $\mathrm{B}$ & Std. Error & & & \\
\hline \multirow[t]{2}{*}{1} & (Constant) & 34.98 & 6.01 & & 5.82 & .00 \\
\hline & CTSNHT & .42 & .10 & .45 & 4.08 & .00 \\
\hline
\end{tabular}

The regression equation analysis of the correlation between CTS and CLO related to the NHT learning model + metacognitive strategy is shown in Table 9. Since the values of $a=21,665$ and $b=0.722$, the regression equation generated in the NHT learning model + metacognitive strategy is $Y=21.665+0.722 X$. 
Table 9. Regression coefficient values between CTS and CLO in the NHT learning model + metacognitive strategy

\begin{tabular}{|c|c|c|c|c|c|}
\hline \multicolumn{6}{|c|}{ Coefficients $^{\mathrm{a}}$} \\
\hline \multirow{2}{*}{\multicolumn{2}{|c|}{ Model }} & Unstandardized Coefficients & $\begin{array}{c}\text { Standardized } \\
\text { Coefficients }\end{array}$ & $\mathrm{T}$ & Sig. \\
\hline & & Std. Error & Beta & & \\
\hline 1 & (Constant) & 21.66 & & 5.64 & .000 \\
\hline & CTSNHT Meta & .05 & .84 & 13.03 & .000 \\
\hline
\end{tabular}

The results of the Anova test of the regression equations on NHT learning model and NHT learning model+ metacognitive strategy are shown in Table 10, while the rate of CTS and CLO is shown in Figure 1.

Table 10. Summary of Anova based on the regression equation between CTS and CLO in the NHT, NHT + metacognitive strategy

\begin{tabular}{ccccccc}
\hline & Model & Sum of Squares & df & Mean Square & F & Sig. \\
\hline 1 & Regression & 10779.23 & 3 & 3593.08 & 67.97 & $0.00^{\mathrm{b}}$ \\
$b 1, b 2$ & 376.13 & 1 & 376.13 & 7.11 & 0.09 \\
& $b 1, b 2, b 3$ & 1313.843 & 2 & 656.92 & 12.43 & 0.00 \\
Residual & 7030.94 & 133 & 52.86 & & \\
Total & 17810.17 & 136 & & & \\
\hline
\end{tabular}

The results of Anova show that the significance value was $b 1, b 2$ is $0.09(p<0.05)$, and the significance value of $b 1, b 2, b 3$ was $0.00(p<0.05)$. These results prove that the regression lines that describe the correlation between CTS and CLO are not parallel and not coincide but intersect. In Figure 1, it is clear that both lines intersect. This means the slopes differ from one another, and so do the intercepts. Thus, the rate of students' CLO due to the effect of critical thinking skill factors differ from one another, and the magnitude of CLO due to the effect of CTS factors are also different from one another. From the graph of the regression equation (Figure 1), it is found that the rate of CLO due to the effect of CTS factor in the NHT learning model + metacognitive strategy is greater than that in the NHT learning model.

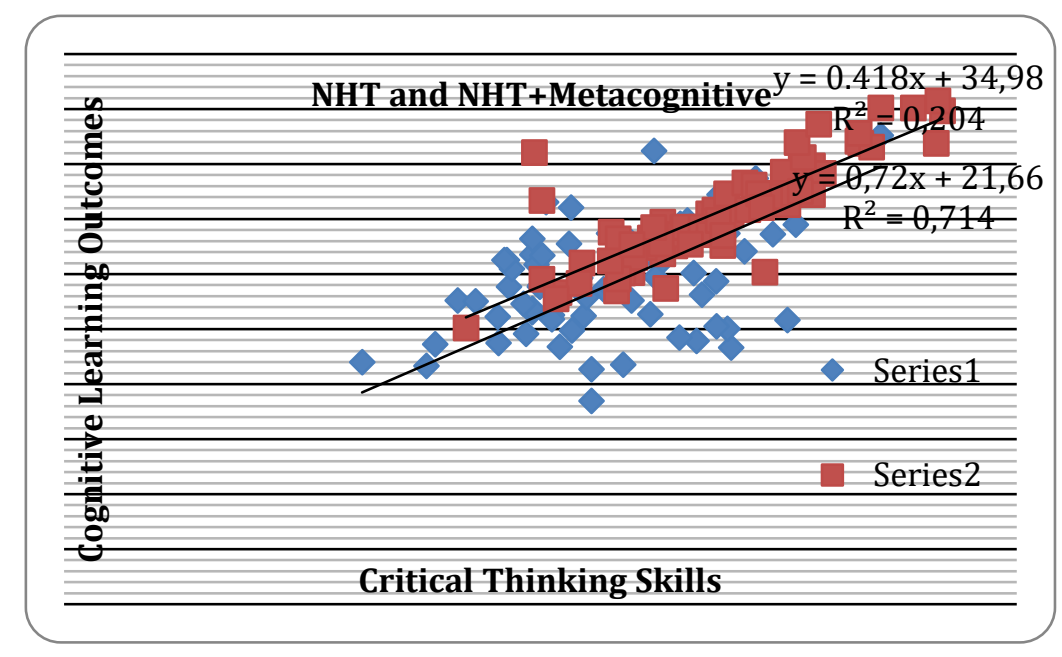

FİGURE 1. Graph of Regression Equation between CTS and CLO 


\section{DISCUSSION and CONCLUSIONS}

\section{Correlation between CTS and CLO in the NHT learning model, NHT + metacognitive strategy}

The results showed that there was a correlation between CTS and CLO in NHT learning model, and NHT learning model + metacognitive strategy. However, the correlation between CTS and CLO in the NHT learning model is moderate, whereas the NHT learning model + metacognitive is very strong. The results of the analysis also informed that there was a positive value of the correlation coefficient in both learning models. Positive correlation means that the increase of CTS score is positively correlated with the increase of CLO, or in other words, the increase of the score of CTS will also results in an increase of the score of CLO. Thus, the empowerment of CTS through NHT learning model and NHT learning model + metacognitive strategy needs to be done because CTS have a substantial contribution in improving students' CLO. This can be seen in Tables 4 and 5 .

NHT is one type of cooperative learning models that is effective in improving students' thinking skills and participation, even in low academic ability students. The NHT learning model has several syntaxes that spur the development of these abilities, including the phase of numbering, questioning, thinking together, and answering (Haydon, Maheady, \& Hunter, 2010). In the numbering phase, students who have been organized in groups (1 group consisting of 4-5 people) are assigned a specific number by the teacher (number between 1-5). The purpose of numbering is to prepare students for the tasks they will do in learning, and to remind students of their responsibilities in the group.

The second phase is questioning. This phase is done by the teacher. Questions to each student can be given in the form of a small card according to the number and in the form of student worksheet. After receiving a small card, each student is given the time to think and complete the task individually (Maheady, Michielli-Pendl, Harper, \& Mallette, 2006). In order to be able to answer the questions well, the students should seek the necessary information by themselves, such as through reading activities. The information obtained is then filtered, whichever is appropriate, logical, and accurate in relation to the question. Thus, this phase requires students to think deeply before finally responding to the given tasks in order that the students with the number have contributions towards the achievement of the group's objectives, and are deemed to be responsible (Davis \& Neitzel, 2010).

The third phase is thinking together (heads together). In this phase, all members of the group discuss and share each question. Each student is encouraged to demonstrate his or her responsibility and activeness in explaining to the other group members. That during cothinking, students propose solutions to problems, assumptions, points of view or information to stimulate other students' responses based on specific questions or statements (Cutumisu, Schwartz, \& Lou, 2020). This phase mobilizes students' critical thinking empowerment because through discussion there will be feedback between peers, so that students think and evaluate various arguments. Ultimately critical thinking will produce the best solution based on the group agreement written in the student worksheet (Gillies, 2011).

The last phase is answering. In this phase, each member of the group has full maturity and readiness to answer the questions from the teacher. Any member who has not reached this point attempts to ripen himself by re-learning, remembering, asking other group members before being entrusted to represent the group in answering the question. The understanding of each student is tested when the question is randomly given, at which point the student declares his final responsibility as a representation of the group, as well as being a critical thinker while posing a logical argument to convince the teacher and the class community.

In addition to the NHT learning model, the NHT learning model + metacognitive strategy also proves to have a strong correlation between critical thinking skills and cognitive learning results. In this model, there are two additional phases that describe the student's metacognition activities performed at the beginning and at the end of the learning. Besides, the other activities still refer to the NHT syntax (Leasa, Corebima, \& Batlolona, 2020). The metacognitive strategy first performed by students is summarizing activity. Before making a summary, the students 
search for relevant information through books or other learning media. The next step is reading or reviewing the information contained in the text, and then making a summary. To summarize, one must develop the topic of the sentence as well as distinguish between important and unimportant details. Summarizing is pulling out important information from the entire information, by reading the entire section in advance. A good summary is an accurate indication of how well the text has been understood. Summarizing is a useful cognitive activity for students to discover the interrelationships between different mainstream idea (Wang \& Yu, 2018). Strategy makes students interpret the text or the material that they have learned. Finally, it encourages students to also think how to organize a summary that has a flow of readings. Summarizing is a complex process. It can continue to improve students' higher-order thinking skills, including critical thinking and learning results (Retnawati, Djidu, Kartianom, Apino, \& Anazifa, 2018).

Self-assessing metacognitive strategy aims to facilitate the control of cognitive activity to become more. In this case, students are expected to understand the strategies they use in completing each task, when, and able to identify irrelevant information and discard it. Students who are able to do it are called independent learners who actively regulate their learning (Ziegler \& Opdenakker, 2018). They have the ability to construct knowledge, to be responsible for the learning process, to think and work in improving their quality to be critical thinkers who are responsive to the learning needs. Such a process ultimately improves students' ability to regulate their critical thinking behaviors to improve the learning outcome (Nandagopal \& Ericsson 2012).

\section{The contribution of critical thinking skills toward learning outcome in the NHT learning model, NHT learning model + metacognitive strategy}

The results of this research show that the learning model that has the biggest contribution of the critical thinking toward cognitive learning results is the NHT learning model + metacognitive strategy with $71.4 \%$, or the other factors have a contribution of $28.6 \%$. This suggests that the NHT learning model + metacognitive strategy has a better efficiency level for empowering students' CTS and CLO. Nevertheless, the NHT learning model still has the potential to empower CTS and learning results, as evidenced by the magnitude of the contribution of the learning model.

The main superiority of the NHT learning model + metacognitive strategy is summarizing. Summarizing is one of the core of cognitive processes to find important information (Abdi, Idris, Alguliyev, \& Aliguliyev, 2016). Summarizing helps students understand the information and transfer it to their long-term memory. When summarizing, students direct their views in reading the text comprehensively in order to understand, rather than simply reading without any intent or purpose. Summarizing is done by eliminating irrelevant information, so that the students get important ideas which are easy to understand. In addition, through this activity students practice to express information using their own words. Such activities require CTS as well as mental skills to link these new ideas with the old ideas, as well as to express authentic ideas and to extract key ideas from the text sources (Zhao, Lin, Sun, \& Liao, 2020).

Research related to the correlation between CTS and CLO is not all based on the application of learning models. For example, Egok (2016) found a significant correlation between critical thinking skills and mathematics learning outcomes of elementary students. The relationship between the two variables is expressed in the equation $Y=0.535 X+20.658$. There are several studies on the correlation between CTS and CLO based on the implementation of learning models. The research by Wicaksono's (2014), through the Reciprocal Teaching (RT) learning strategy, revealed that metacognitive skills and cognitive learning results have a contribution of $72.7 \%$ toward cognitive learning results. The relative contribution values of metacognitive skill and critical thinking skills toward cognitive learning results were $42.23 \%$ and $57.77 \%$, respectively, while the effective contributions were $30.70 \%$ and $41.99 \%$, respectively. Thus, it is evident that critical thinking skills have bigger contribution toward cognitive learning results than the metacognitive skill does. Pu et al., (2019) reported that there 
was a significant positive relationship observed between critical thinking disposition scores and learning outcomes using PBL-based tutorial learning, where students' critical thinking dispositions influenced their performance during PBL tutorials. In line with that Bustami (2020) also reported that critical thinking skills contributed $41 \%$ to students' conceptual understanding of the human digestive system material. The regression equation generated from the correlation of the two variables is $Y=0.736 X+22.861$.

Group Investigation (GI) learning model reveals the effective contribution value of CTS toward learning outcome is $73.9 \%$. Malahayati (2014) reports that metacognitive skill and CTS have relative contributions of $38.47 \%$ and $61.53 \%$ toward learning outcome through the problem-based learning model. While the effective contribution values of both variables respectively were $28.86 \%$ and $46.16 \%$ toward the learning results. This means that CTS have much bigger contribution toward the learning results than the metacognitive skills do. From the results of these research, it is known that CTS have a much greater contribution toward students' learning outcome, when compared with the other variables (Mite \& Corebima, 2017).

\section{The difference in regression equations in NHT learning model, NHT learning model + metacognitive strategy}

Based on the results of Anova test, it was found that both regression lines intersect. This means that the rate and the magnitude of CLO as a result of the effect of CTS are different from each other. In addition, the biggest value of slope or rate CLO due to the effect of CTS factor is found in the NHT learning model + metacognitive strategy. The results of Anova are very much in line with the value of correlation coefficient $(r)$ between CTS and cognitive learning results. In the NHT learning model + metacognitive strategy, the $r$ value was as much as 0.845 , or included as very strong correlation level, whereas in the NHT learning model, the $r$ value was only 0.451 , or classified as moderate correlation level. These results are also relevant to the magnitude of the contribution of CTS factor toward students' CLO in the NHT learning model + metacognitive strategy that reached 71.4, compared with the contribution of NHT learning model, which was as much as 20.4 .

These findings confirm that NHT learning model + metacognitive strategy has greater potential or excellence in improving students' CLO through empowering CTS than NHT learning model does. Simply, it can be concluded that NHT learning model + metacognitive strategy is more effective in empowering students' CTS and CLO. However, NHT learning model is also effective in empowering students' CTS and CLO. This can be seen from the contribution of each learning model. Therefore, the empowerment of CTS and CLO is not yet sufficient only by using the NHT learning model, but it needs to be complemented with metacognitive strategies (Leasa, 2017).

In the NHT learning, students have some time to think deeply in finding accurate solutions to the problems discussed. The interactions among the students are also very helpful in strengthening students' long-term understanding and memory of each solution that has been discussed in the phase of head together. The NHT learning model also emphasizes the students' participation in learning specifically in expressing the solution that has been well thought of. Thus, the students are ready to convey their thoughts at any time. The learning model can provide opportunities for students to think more deeply, analyze, formulate, and decide the right solution / answer to be accounted for (Leasa, Talakua, \& Batlolona, 2016) .

The use of metacognitive strategies has often been discussed at the conceptual level as an important factor affecting critical thinking (Acar \& Ader, 2017). Metacognitive strategies allow students to supervise and control their own thinking processes. The metacognitive strategies used in developing critical thinking usually fall into three categories: planning, monitoring, and evaluation. Learning needs to be supported with appropriate metacognitive strategies (Yilmaz \& Baydas, 2017). In this research, the metacognitive strategy was done in 2 forms, namely the summarizing activity that occurred before the learning process, and self-assessing activity that occurred at the end of learning. The summarizing activity helps students recognize and 
understand the information to be learned. The activity allows students to read and write, so that it helps store information in their cognitive structure. While self-assessment is a form of reflection on the learning process done by the students. The activity is a form of monitoring and evaluation of the learning performance. It is expected that these activities can be part of the contemplation and improvement of learning activities and students' cognitive regulation in the future (Dunlonsky et al., 2013).

Related to it, there are several research results that reveal the role of NHT learning model in improving students' CTS and CLO. The research by Nursyamsi (2016) reveals that NHT learning model has an effect on students' CTS as much as $25.89 \%$ larger than the conventional learning model. The corrected mean score of the retention of students learning by using NHT learning model is $24.3 \%$ higher than that using conventional learning model (Nursyamsi \& Corebima, 2016). Similarly, Maasawet (2009) also reveals that the Snowballing and NHT learning strategies are potential in empowering students' critical thinking skills, cognitive learning results, and social attitudes in multi-ethnic schools. The Cooperative Script (CS) and Reciprocal Teaching (RT) strategy combined with metacognitive strategy can improve students' metacognitive skills, CTS, biology learning outcome, and retention (Siswati \& Corebima, 2017). The implementation of the NHT learning model is observed in Science-Biology learning for fifthgrade elementary school students. The cognitive learning outcomes of students taught by conventional learning models increased by $20.03 \%$, while the increase in cognitive learning outcomes in groups of students taught with cooperative learning models reached $155.43 \%$. Thus, it is concluded that students who receive NHT learning have higher cognitive learning outcomes than students who receive conventional learning (Leasa \& Corebima, 2017). Other research results reveal that cognitive learning outcomes in mathematics given the NHT cooperative learning model combined with the concept map were better than the learning outcomes of students who were given the TGT cooperative learning model with the concept map and direct learning model (Irawan, Mardiyana, \& Saputro, 2017).

The results of this research showed that there was a correlation between CTS and CLO with $r$ values of NHT learning model and NHT + metacognitive strategy were 0.451 and 0.845 respectively. The NHT learning model + metacognitive strategy had a contribution of CTS toward CLO as much as $71.4 \%$ compared that of NHT learning model as much as $20.4 \%$. The results of Anova related to the regression equations in the NHT learning model and NHT + metacognitive strategy showed that both regression lines were intersected. This means the rate and the magnitude of cognitive learning results due to the effect of CTS were different from each other. It was also found that the biggest value of slope or rate of students' CLO due to the effect of CTS was in the NHT learning model + metacognitive strategy. This shows that the potential for the improvement of students' cognitive learning results due to the CTS factor was in the NHT + metacognitive strategy. In other words, the NHT learning model + metacognitive strategy is more effective in empowering students' CTS and CLO (Leasa, 2017). However, the NHT learning model is also effective in empowering students' CTS and CLO. Thus, the NHT learning model + metacognitive strategy can be recommended to be implemented in science learning or other learning to empower CTS and CLO.

\section{REFERENCES}

Abdi, A., Idris, N., Alguliyev, R. M., \& Aliguliyev, R. M. (2016). An automated summarization assessment algorithm for identifying summarizing strategies. PLoS ONE, 11 (1), 1-34. https://doi.org/10.1371/journal.pone.0145809

Acar, F., \& Ader, E. (2017). Matematikte akran öğretimi sırasında öğretici görevi üstlenen öğrencilerde üstbiliş. Elementary Education Online, 16 (3), 1185-1200. https://doi.org/10.17051/ ilkonline.2017.330250

Akpur, U. (2020). Critical, Reflective, creative thinking and their reflections on academic achievement. Thinking Skills and Creativity. https://doi.org/10.1016/j.tsc.2020.100683

Almeida, L. S., \& Franco, A. H. R. (2011). Critical thinking; its relevance for education in a shifting society. Revista de Psicologia, 29 (1), 176-195 
Amin, A. M., Corebima, A. D., Zubaidah, S., \& Mahanal, S. (2020). The correlation between metacognitive skills and critical thinking skills at the implementation of four different learning strategies in animal physiology lectures. European Journal of Educational Research, 9 (1), 143-163. https://doi.org/10.12973/eu-jer.9.1.143

Bustami, Y., Leliavia, L., Elisabeth, N., Gandasari, A., \& Ratnasari, D. (2020). Contextual teaching and learning in human digestive system: the contribution of critical thinking skills. Biosfer: Jurnal Pendidikan Biologi, 13 (1), 101-113. https://doi.org/10.21009/biosferjpb.v13n1.10

Cai, Y., King, R. B., Law, W., \& McInerney, D. M. (2019). Which comes first? modeling the relationships among future goals, metacognitive strategies and academic achievement using multilevel crosslagged SEM. Learning and Individual Differences, 74. https://doi.org/10.1016/j.lindif.2019.06.004

Cheng, M. H. M., \& Wan, Z. H. (2017). Exploring the effects of classroom learning environment on critical thinking skills and disposition: a study of Hong Kong 12th graders in liberal studies. Thinking Skills and Creativity, 24, 152-163. https://doi.org/10.1016/j.tsc.2017.03.001

Cohen, L., Manion, L., \& Morrison, K. (2000). Research Methods in Education. New York: Routledge. https://doi.org/10.1016/j.tsc.2020.100683

Cutumisu, M., Schwartz, D. L., \& Lou, N. M. (2020). The relation between academic achievement and the spontaneous use of design-thinking strategies. Computers and Education, 149, 103806. https://doi.org/10.1016/j.compedu.2020.103806

D'Alessio, F. A. D., Avolio, B. E., \& Charles, V. (2019). Studying the impact of critical thinking on the academic performance of executive MBA students. Thinking Skills and Creativity, 31, 275-283. https://doi.org/10.1016/j.tsc.2019.02.002

Danczak, S. M., Thompson, C. D., \& Overton, T. L. (2020). Development and validation of an instrument to measure undergraduate chemistry students' critical thinking skills. Chemistry Education Research and Practice, 21 (1), 62-78. https://doi.org/10.1039/c8rp00130h

Davis, D. S., \& Neitzel, C. (2010). The relationship between students' reading orientations and their strategic activity during a collaborative reading task. Reading Psychology, 31 (6), 546-579. https://doi.org/10.1080/02702710903256593

Downing, K., Ning, F., \& Shin, K. (2011). Impact of problem-based learning on student experience and metacognitive development. Multicultural Education and Technology Journal, 5 (1), 55-69. https://doi.org/10.1108/17504971111121928

Dunlosky, J., Rawson, K. A., Marsh, E. J., Nathan, M. J., \&. Willingham, D. T. (2013). Improving students' learning with effective learning techniques: promising directions from cognitive and educational psychology. Psychological Science in the Public Interest, 14 (1), 4-58. https://doi.org/ 10.1177/1529100612453266

Egok, A. 2016. Critical thinking ability and independent learning with mathematics learning outcomes. [Text in Indonesian]. Jurnal Pendidikan Dasar, 7 (2), 186-199

Erikson, M. G., \& Erikson, M. (2019). Learning outcomes and critical thinking-good intentions in conflict. Studies in Higher Education, 44 (12), 2293-2303. htps ://doi.org/ 10.1080/03075079.2018.1486813

Facione, P. (2016). Critical thinking: a statement of expert consensus for purposes of educational assessment and instruction executive summary. The Delphi Report.

Facione, P. (2011). Critical Thinking : what it is and why it counts. in insight assessment. Retrieved from https://www.insightassessment.com/CT-Resources/Teaching-For-and-About-Critical-Thinking/ Critical- Thinking-What-It-Is-and-Why-It-Counts/Critical-Thinking-What-It-Is-and-Why-It-CountsPDF

Fong, A. C. J., Kim, Y., Davis, C. W., Hoang, T., Kim, Y. W., \& Kim, Y. W. (2017). A meta-analysis on critical thinking and community college student achievement. Thinking Skills and Creativity. https://doi.org/10.1016/j.tsc.2017.06.002

Galloway, K. R., \& Bretz, S. L. (2015). Using cluster analysis to characterize meaningful learning in a firstyear university chemistry laboratory course. Chemistry Education Research and Practice, 16 (4), 879-892. https://doi.org/10.1039/c5rp00077g

George-Williams, S. R., Karis, D., Ziebell, A. L., Kitson, R. R. A., Coppo, P., Schmid, S., \& Overton, T. L. (2019). Investigating student and staff perceptions of students' experiences in teaching laboratories through the lens of meaningful learning. Chemistry Education Research and Practice, 20 (1), 187196. https://doi.org/10.1039/c8rp00188j

Gillies, R. M. (2011). Promoting thinking, problem-solving and reasoning during small group discussions. Teachers and Teaching: Theory and Practice, 17 (1), 73-89. https://doi.org/ 10.1080/ 13540602.2011 .538498

Haydon, T., Maheady, L., \& Hunter, W. (2010). Effects of numbered heads together on the daily quiz scores 
and on-task behavior of students with disabilities. Journal of Behavioral Education, 19 (3), 222-238. https://doi.org/10.1007/s10864-010-9108-3

Hulleman, C. S., \& Harackiewicz, J. M. (2009). Promoting interest and performance in high school science classes. Science, 326 (5958), 1410-1412. https://doi.org/10.1126/science.1177067

Hunter, W. C., Dieker, L. A., \& Whitney, T. (2016). Consultants and coteachers affecting student outcomes with numbered heads together: keeping all engaged. Journal of Educational and Psychological Consultation, 26 (2), 186-199. https://doi.org/10.1080/10474412.2015. 1108200

Hunter, W., \& Haydon, T. (2013). Examining the effectiveness of numbered heads together for students with emotional and behavioral disorders. Beyond Behavior, 22 (3), 40-45. https://doi.org/10.1177/107429561302200306

Irawan, A., Mardiyana., \& Saputro, D. W. S. (2017). Experimentation of cooperative learning model numbered heads together (nht) type by concept maps and teams games tournament (tgt) by concept maps in terms of students logical mathematics intellegences. IOP Conf. Series: Journal of Physics: Conf. Series, 855,012019. https//doi.org/10.1088/1742-6596/855/1/012019.

Jacob, S. M. (2012). Social Mathematical achievement and critical thinking skills in asynchronous discussion forums. 31, 800-804. https://doi.org/10.1016/j.sbspro.2011.12.144

Kanbay, Y., Isik, E., Aslan, O., Tektas, P., \& Kilic, N. (2017). Critical thinking skill and academic achievement development in nursing students: four-year longitudinal study. American Journal of Educational Research and Reviews, 2 (12), 1-10

Karbalaei, A. (2012). Critical thinking and academic achievement. Ikala, 17 (2), 121-128

Krathwohl, D.R. (2002). A revision of bloom's taxonomy: an overview. Teory into Practice, 41 (4), 212-218

Leasa, M., Talakua, M., \& Batlolona, J. R. (2016). The development of a thematic module based on numbered heads together (nht) cooperative learning model for elementary students in Ambon, Moluccas-Indonesia. New Educational Review, 46 (4), 174-185. https://doi.org/10.15804/ tner.2016.46.4.15

Leasa, M. \& Corebima, A. D. (2017). The contribution of emotional intelligence toward students ' learning results in science learning using nht learning model-metacognitive strategies. Scholars Journal of Arts, Humanities and Social Sciences, 5, 550-556. https://doi.org/10.21276/sjahss

Leasa, M. (2017). The effect of nht cooperative learning combined with metacognitive strategies, and learning styles on elementary school students' emotional intelligence, critical thinking skills, and cognitive achievement in ambon city. [Text in Indonesian]. Unpublished doctoral dissertation, State University of Malang, Malang, Indonesia

Leasa, M., Corebima, A. D., Batlolona, J. R. (2020). The effect of learning styles on the critical thinking skills natural science of elementary school students. Ilkogretim Online - Elementary Education Online, 19 (4), 2086-2097. https:// doi:10.17051/ilkonline.2020.763449

López, M., Jiménez, J. M., Martín-Gil, B., Fernández-Castro, M., Cao, M. J., Frutos, M., \& Castro, M. J. (2020). The impact of an educational intervention on nursing students' critical thinking skills: A quasiexperimental study. Nurse Education Today, 85, 104305. https://doi.org/10.1016/ j.nedt.2019.104305

Maasawet, E. T. (2009). The effect of snowballing and numbered heads together (nht) cooperative learning strategies in multiethnic schools on critical thinking skills, cognitive achievement of biological science and social attitude of junior high school students in Samarinda. [Text in Indonesian]. Unpublished doctoral dissertation, State University of Malang, Malang, Indonesia

Maheady, L., Michielli-Pendl, J., Harper, G. F., \& Mallette, B. (2006). The effects of numbered heads together with and without an incentive package on the science test performance of a diverse group of sixth graders. Journal of Behavioral Education, 15 (1), 25-39. https://doi.org/10.1007/s10864005-9002-6

Malahayati, E. N. (2014). The correlation between metacognitive skills and critical thinking skills with the biology learning outcomes of students who undergo problem based learning (pbl) in class XI high school students in Malang. [Text in Indonesian]. Unpublished magister thesis, State University of Malang, Malang, Indonesia

Maasawet, E. T. (2009). The effect of snowballing and numbered heads together (nht) cooperative learning strategies in multiethnic schools on critical thinking skills, cognitive achievement of biological science and social attitude of junior high school students in Samarinda. [Text in Indonesian]. Unpublished doctoral dissertation, State University of Malang, Malang, Indonesia

Marcos, R. I. S., Ferández, V. L., González, M. T. D., \& Silver, J. P. (2020). Promoting children's creative thinking through reading and writing in a cooperative learning classroom. Thinking Skills and Creativity, 36, 1-13

Mathew, J. S. (2017). Self-perception and academic achievement. Indian Journal of Science and Technology, 
10 (14), 1-6. https://doi.org/10.17485/ijst/2017/v10i14/107586

Mite, Y., \& Corebima, D. A. (2017). The correlation between critical thinking and the learning results of the senior high school students in biology learning implementing group investigation (gi) learning in Malang, Indonesia. Journal of Applied and Advanced Research, 2 (2), 56. https://doi.org/10.21839/jaar.2017.v2i2.57

Nandagopal, K., \& Ericsson, K. A. (2012). An expert performance approach to the study of individual differences in self-regulated activities in upper-level college students. Learning and Individual Differences, 22 (5), 597-609. https://doi.org/10.1016/j.lindif.2011.11.018

Nursyamsi, S. Y., \& Corebima, A. D. (2016). The effect of numbered heads together (nht) learning strategy on the retention of senior high school students in muara badak, east Kalimantan, Indonesia. European Journal of Education Studies, 2 (5), 47-58. https://doi.org/10.5281/zenodo.154450 European

Peter, A., \& Facione, N. C. (2013). Critical thinking for life: valuing, measuring, and training critical thinking in all its forms. Spring, 28 (1), 5-25

Pu, D.,Ni, J., Song. D., Zhang., W., Wang, Y., Wu, L., Wang, X., \& Wang, Y. (2019). Influence of critical thinking disposition on the learning efficiency of problem-based learning in undergraduate medical students. BMC Medical Education, 19 (1), 1-8

Retnawati, H., Djidu, H., Kartianom, Apino, E., \& Anazifa, R. D. (2018). Teachers' knowledge about higherorder thinking skills and its learning strategy. Problems of Education in the 21st Century, 76 (2), 215-230

Shannon, S. (2008). Using metacognitive strategies and learning styles to create self-directed learners. Institute for Learning Styles Journal, 1, 14-28

Shirazi, F., \& Heidari, S. 2019. The relationship between critical thinking skills and learning styles and academic achievement of nursing students. The Journal of Nursing Research, 27 (4), 1-7. https://doi: 10.1097/jnr.0000000000000307

Siswati, B. H., \& Corebima, A. D. (2017). Study on the correlation between metacognitive skills and concept gaining of biology at several learning models. Asia-Pacific Forum on Science Learning and Teaching, 18 (1), 1-14.

Slavin, R. E. (2014). Cooperative learning and academic achievement: why does groupwork work? Four major theoretical perspectives on cooperative learning and achievement. Anales de Psicología, 30 (3), 785-791. http://dx.doi.org/10.6018/analesps.30.3.201201

Sugiharto. (2020). Geographical students' learning outcomes on basic political science by using cooperative learning model with group investigation (gi) type in state university of Medan, Indonesia. Journal of Human Behavior in the Social Environment, 30 (4), 1-10. https://doi.org/10.1080/10911359.2019.1696261

van Peppen, L. M., Verkoeijen, P. P. J. L., Heijltjes, A. E. G., Janssen, E. M., Koopmans, D., \& van Gog, T. (2018). Effects of self-explaining on learning and transfer of critical thinking skills. Frontiers in Education, 3, 1-11. https://doi.org/10.3389/feduc.2018.00100

Veenman. M. V. J. (2011). Learning to self-monitor and self-regulate. In: Mayer, R. E. and Alexander, P. A. (Eds.). Handbook of Research on Learning and Instruction (pp.197-218). New York and London: Routledge

Wagaba, F., Treagust, D. F., Chandrasegaran, A. L., \& Won, M. (2016). Using metacognitive strategies in teaching to facilitate understanding of light concepts among year 9 students. Research in Science and Technological Education, 34 (3), 253-272. https://doi.org/10.1080/02635143.2016.1144051

Wang, H., \& Yu, G. (2018). Test-Takers' cognitive processes during a listen-to-summarize cloze task. International Journal of Listening, 1-28. https://doi.org/10.1080/10904018.2018.1473040

Wartono, W., Hudha, M. N., \& Batlolona, J. R. (2018). How are the physics critical thinking skills of the students taught by using inquiry-discovery through empirical and theorethical overview? Eurasia Journal of Mathematics, Science and Technology Education, 14 (2). https://doi.org/10.12973/ejmste/80632

Wei, B. (2020). The change in the intended senior high school chemistry curriculum in china: focus on intellectual demands. Chemistry Education Research and Practice, 21 (1), 14-23. https://doi.org/10.1039/c9rp00115h

Wicaksono, A. G. C. (2014). The correlation betweeen metacognitive skills and critical thinking skill toward cognitive learning results of senior high school students on biology learning with reciprocal teaching strategy in Malang. [Text in Indonesian]. Unpublished magister thesis, State University of Malang, Malang, Indonesia

Yilmaz, R. M., \& Baydas, O. (2017). An examination of undergraduates' metacognitive strategies in preclass asynchronous activity in a flipped classroom. Educational Technology Research and 
Development, 65 (6), 1547-1567. https://doi.org/10.1007/s11423-017-9534-1

Zhao, J., Lin, L., Sun, J., \& Liao, Y. (2020). Using the summarizing strategy to engage learners: empirical evidence in an immersive virtual reality environment. Asia-Pacific Education Researcher. https://doi.org/10.1007/s40299-020-00499-w

Ziegler, N., \& Opdenakker, M. C. (2018). The development of academic procrastination in first-year secondary education students: the link with metacognitive self-regulation, self-efficacy, and effort regulation. Learning and Individual Differences, 64, 71-82. https://doi.org/10.1016/ j.lindif.2018.04.009

Zohar, A. (2013). Challenges in wide scale implementation efforts to foster higher order thinking (hot) in science education across a whole school system. Thinking Skills and Creativity. https://doi.org/10.1016/j.tsc.2013.06.002 